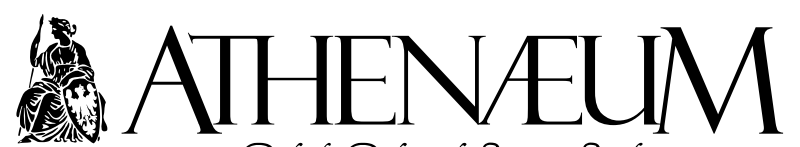

Polish Political Science Studies

Polskie Studia Politologiczne

vol. $67(3) / 2020$, pp. $72-83$

DOI:10.15804/athena.2020.67.05

www.athenaeum.umk.pl

ISSN 1505-2192

\title{
THE ROLE OF FOREIGN MEDIA AND DATA TRANSFER DEVICES IN CHANGING THE VIEWS OF THE DEMOCRATIC PEOPLE'S REPUBLIC OF KOREA'S CITIZENS
}

\author{
ROLA ZAGRANICZNYCH MEDIÓW I ŚRODKÓW \\ PRZEKAZYWANIA DANYCH W ZMIENIANIU \\ ŚWIATOPOGLĄDU OBYWATELI KOREAŃSKIEJ REPUBLIKI \\ LUDOWO-DEMOKRATYCZNEJ
}

Nicolas Levi*๑, Kamil Weber**

\begin{abstract}
North Korea is often seen as the most isolated country in the world. This isolation may be one of the key factors ensuring the rule of the Kim's family. For the last several years, however, the information barrier has been increasingly violated there. This article therefore describes how information is provided to the DPRK and examines whether this process can cause significant socio-political changes in North Korea.
\end{abstract}

Keywords: North Korea; transfer of information; pro-democracy activists; support for the regime
Korea Północna często postrzegana jest jako najbardziej odizolowane państwo świata. Izolacja ta może być jednym z kluczowych czynników zapewniających trwanie tamtejszego reżimu rodziny Kimów. Od kilkunastu lat jednak bariera informacyjna zaczyna być tam coraz częściej naruszana. Artykuł ten opisuje zatem sposoby przekazywania informacji do KRLD oraz stanowi analizę tego, czy proces ten może spowodować w Korei Północnej znaczące zmiany społeczno-polityczne.

Słowa kluczowe: Korea Północna; przepływ informacji; aktywiści prodemokratyczni; poparcie władz

* Polish Academy of Sciences, Institute of Mediterranean and Oriental Cultures.

** Central Museum of Prisoners-of-War in Opole. 


\section{INTRODUCTION}

The growing flow of information from the outside world to the Democratic People's Republic of Korea (DPRK) ${ }^{1}$ several years ago prompted some analysts to think that this could cause significant changes and undermine the local political system. It is worth considering whether the consequences of this process may indeed be so far-reaching. This issue is not yet exhaustively shown in the scientific literature. Often, however, there are reports of news agencies that concern the transfer of information to North Korea. They show these events in a fragmented way, although the increasing number of such news confirms the scale of this phenomenon. In this case, it is necessary to take into account the activities of foreign media broadcasting signals to the DPRK's territory and the smuggling of memory media across the border with China. Another way to send information to a state controlled by Kim Jong- $\mathrm{un}^{2}$ is sending the various types of leaflets by activists using balloons and drones. This form of action is exclusively delivered by refugees' NGO (Lankov, 2012, p. 226). These increasingly large-scale attempts to disseminate information about the real face of the DPRK regime should be contrasted with the efforts of the state authorities to keep citizens in isolation and disinformation. This should allow to answer questions about the potential consequences of the collision of these processes and their impact on the views of Koreans from the North, and thus - the durability of Kim Jong-un's power. It seems that despite the growing of this phenomenon and the emergence of votes of North Korean refugees about its significant impact on the stability of the regime, the effect will not be very significant in the near future. It is worth emphasizing that research on North Korean refugees is conducted on a group of people whose views often do not reflect the mood of majority of the North Korean society. This is due, among other things, to the fact that those who escape from DPRK are mostly uneducated women from the northern provinces of this country. The data provided by such research have, therefore, only informative meaning. It is therefore important to analyze the situation currently prevailing in North Korea, taking into account a wide range of factors affecting it.

\footnotetext{
1 Also called: North Korea.

2 The transcription of Korean names remains a challenging issue. This article generally follows the McCune-Reischauer system or the most popular forms. Korean names are written in different ways not only in Latin script languages, but also in the Korean language variants themselves. For example, Lee’s transcript is written "I" (이) in South Korea and "Ri" (리) in North Korea.
} 
Regarding the methodology, the article uses a combination of quantitative and qualitative methods and source criticism to analyze the mentioned topic. The whole is done to develop important observations and draw conclusions.

This article supports the hypothesis and theoretical conclusion that information play a crucial role in the establishment and continuity of the DPRK dictatorial political system.

To fulfill these aims, the paper divides the discussed subject into three chapters. The first one consists of a short outline of the transfer of foreign information to the DPRK. The second topic tackles the behavior of the DPRK authorities toward the inflow of foreign information. The last chapter describes the potential influence of foreign information on the DPRK population.

\section{THE TRANSFER OF FOREIGN INFORMATION TO THE DPRK}

The North Korean audience is targeted by Public and Private western initiatives. The first category is dominated by Radio Free Asia and Voice of America which are state (US) sponsored projects. The second category gathers defector-based stations which lack funds and cannot develop themselves in spite of their broad knowledge of North Korea.

The sources of information sent to North Korea can be divided into two groups. The first are those related to entertainment - various types of media and memory cards containing mainly films and TV programs originally broadcast in South Korea and China. They are delivered, among others, by traders largely from North Korean provinces that border China. The second group is foreign media reporting on the real face of the outside world and the manipulations of North Korean authorities. Often, the delivery of these messages requires the involvement of other countries and non-governmental organizations operating in them (Lankov, 2012, pp. 26-27). In DPRK the most popular carrier of external information are smuggled DVDs. In the research of Nat Kretchun and Jane Kim from 2010, which were attended by North Korean refugees, 39 percent of them indicated DVDs as an important source of news in their homeland (Kretchun \& Kim, 2012, p. 10). However, these researches show that none of the surveyed refugees dared to watch them in a wider circle than family or trusted friends. An additional survey concluded that in 2009, the DVD penetration rate was around twenty percent (Kretchun \& Kim, 2012, p. 103). Watching a South Korean show still remains illegal and possession of 
them is subjected to severe punishment. These absurd regulations are ignored by the population. Furthermore, owning a DVD player is authorized by the law (Lankov, 2014, pp. 16-17).

In 2012, representatives of such radio stations as: Radio Free North Korea, Open Radio for North Korea, and Radio Free Chosun, started cooperation in order to establish the Association of Broadcasters for North Korea. Their aim was to exert pressure on the DPRK's authorities to provide greater access to information for citizens of this country (Sedaghat, 2014).

South Korean radio stations often broadcast in the evenings and even late at night, when it is easier for the listeners to track the broadcast and tune in without risking being caught (Chun, 2008). The aforementioned research from 2010 showed, for example, that seventy-five percent of surveyed refugees listened to foreign radio between $11 \mathrm{p}^{\mathrm{m}}$ and midnight. On the other hand, in the afternoon (from $1 \mathrm{p}^{\mathrm{m}}$ to $6 \mathrm{pm}$ ), only one in a hundred people listened to these programs (Kretchun \& Kim, 2012, p. 20). Listening to foreign stations is also hindered by the fact that radio and TV receivers must be tuned in such a way that they play only the North Korean radio stations (Ziccardi, 2013, p. 296). Earlier, receivers are also checked by and registered with the police (Sedaghat, 2014). In addition, controls are made at home every three months to verify that the receivers have not been tuned (Kretchun \& Kim, 2012,p. 73). The Central Agency for the Safety of Science and Communication Technology has an important role to oversee citizens. This office monitors the activity of TV, radio and Internet users, and the task of its employees is, among others, setting appropriate locks in the receivers (Demick, 2011, p. 223). Some North Koreans keep two radios at home. One to show the controllers and the other to listen (Higginbotham, 2014). The authorities, however, use an advanced radio jamming system (Colors, 2013). The effects of the inflow of external information are also counteracted by numerous national and local radio stations, strengthening support for leaders. There are even those that target their programs especially for soldiers guarding the border with the South (BBC, 2011).

Watching foreign television stations is also difficult in North Korea and is subject to various restrictions. Except several hotels and administrations in cities such as Pyongyang and Rason, there is no access to satellite television. This means that receiving external stations is only possible in areas near the borders with China and South Korea. As mentioned, it is illegal and theoretically receivers should not even have such a technical possibility. The signal usually reaches from fifty to seventy-five miles deep into the country. Chinese television Yanji TV is 
the most popular at the border with China, while KBS is often watched in areas near South Korea. In comparison to the number of recipients of North Korean state television, the number of people watching foreign stations is relatively small (Kretchun \& Kim, 2012, p. 15). According to data from 2012, about one third of people who have a TV and live close to a border, had the opportunity to receive foreign broadcasts (Freedom House, 2016). In the research referred to the group of refugees, 38 percent of them said that state television has an important influence. While Chinese television was only indicated by 13 percent of surveyed and South Korean by five percent (Kretchun \& Kim, 2012, p. 10).

The third medium that could provide access to foreign information is the Internet. The number of computers exceeds 100,000 pieces and reached several times more people in North Korea (Lankov, 2014, p. 103). Among the surveyed refugees from North Korea, only 16 percent of them had such an opportunity. However, many offices, military units and schools have these devices (Lankov, 2014, p. 57). The fact of having a computer should be reported to the local branch of the Ministry of Public Security. Hard disks are thoroughly checked for the inclusion of anti-socialist material and content (Lankov, 2014, p. 72). As of 2012, there was only one Internet cafe in Pyongyang (Lee, 2012). In addition, one is discouraged to attend such places with a very high price of up to $\$ 10$ per hour, which is the average monthly wage (Ziccardi, 2013, p. 299). This means that the vast majority of citizens simply cannot afford to use these services. Moreover, computers in North Korea are connected to Chinese servers and subjected to strict data filtration (Ziccardi, 2013, p. 299). However, there is a limited group of people in DPRK who have access to a real, uncensored Internet - probably only a few dozen families closest to the leader (Lee, 2012). Lecturers and $\mathrm{PhD}$ students from the University of Science and Technology in Pyongyang also have access to the Internet, however their activity is closely monitored there ${ }^{3}$. They use the network mainly to find the necessary scientific information, and each e-mail must be approved by the university authorities before being sent (Talmadge, 2014). The Internet - under controlled conditions - is also available in some offices that cooperate with foreign companies.

The method of providing information, which is difficult to counteract for the North Korean authorities, is sending goods there, using special balloons. They fly up to 5,000 meters above sea level, so they are very difficult to shoot down (Sang-hun, 2016). Balloons with a cylindrical shape are filled with helium or

\footnotetext{
3 Also known as the Kim Chaek University of Technology.
} 
hydrogen (Faiola, 2005). Their length is about 12 meters. The distance they reach depends on the strength of the wind and the type of construction (McDonald, 2011). As an effort aimed at pressing the North Korean regime, balloons also transport one-dollar coins, various types of digital storage media and leaflets to denounce the propaganda of the Kim Jong-un's regime (Sang-hun, 2016). The content of these pendrives include subversive media and information, or even copied Wikipedia pages. DVDs, in turn, contain popular television programs from South Korea. These one-dollar coins allow the purchase of rice on the black market (Farivar, 2014). These activities are co-financed by foreign church associations and international organizations fighting for Human Rights Conditions, such as the Defense Forum Foundation (Jung, 2014, p. 29).

Among the groups that deal with the transfer of balloons the following can be mentioned: Fighters for Free North Korea (FFNK), Campaign for Helping North Koreans in Direct Way (NKDW), North Korean Christian Association (NKCA), and North Korean People's Liberation Front (NKPLF) (북한 인민해방 전선, Bukhan Inmin Haebangjeonseon) (Jung, 2014, p. 29). Many of the so-called 'balloon warriors' are former refugees from North Korea.

The founder of the Fighters for Free North Korea - Park Sang-hak ${ }^{4}$ - admitted that only until the beginning of 2014 his group dropped some 52 million leaflets to the DPRK's territory especially designed for the North Korean audience (Farivar, 2014). In the past, also books were sent, but due to the changes in technology, materials started to be scanned instead of being photocopied, which proved to be time and money consuming. The apparition of drones increases the vulnerability of the North Korean regime, which stocks data using SD cards and USB memories (Russon, 2016). At the end of 2015, across the border with China, activists sent 2,000 pendrives to North Korea, but it is still difficult to assess the impact of these launches (Shim, 2015). The website "flashdrivesforfreedom.org" indicates that activists reached around one million people through that kind of actions ${ }^{5}$. Unfortunately, it seems to be impossible to verify this data.

These efforts shall be continued but their impact can be limited as the border between South and North Korea is tightly controlled on both sides. This initiative would be more efficient being done from the Chinese border. However, in this case, requesting the approval of the Chinese authorities would be needed.

${ }^{4}$ Park Sang-hak, before he fled to South Korea, was an official in the propaganda department of the Kimilsungist-Kimjongilist Youth League. He fled to South Korea in 1999.

5 This is a cumulated value till 2018. Retrieved from: https://flashdrivesforfreedom.org. 
This issue was also deepen by the Google project, which tested the possibility of providing access to the Internet thanks to devices attached to balloons (Farivar, 2014).

However, a lot of people criticize such methods, believing that this only provokes the aggression of the regime from Pyongyang. Residents of South Korean villages are afraid that as a result of the actions of activists sending goods to the DPRK, they will be targeted by the authorities. The North Korean authorities regard these actions as a war act and in retaliation they threatened to use the artillery (Sang-hun, 2016), which was the case, for example, in October 2014 (The Guardian, 2015). A retaliatory action taken by DPRK was to send leaflets to the South, on which president Park Geun-hye was called a snake and a prostitute (Sang-hun, 2016). In January 2016, balloons were sent to South Korea, which could transport up to one million prospects.

Some commentators claim that sending balloons has little chance of success. In their opinion, it is hard to know where it would fly, because even when the wind blows north it is possible that the balloons fall into the sea or that most of them end up in the hilly province of Gangwon (Jung, 2014, p. 30). Andrei Lankov - professor at the South Korean Kookmin University - also expressed skepticism about the effectiveness of the impact of leaflets on the situation in North Korea, because in his opinion, it is difficult for a brochure to be able to reverse the prolonged influence of propaganda. However, there is no reliable information on how many Koreans from the North read such leaflets and what is the effect of this (Sang-hun, 2016).

\section{THE BEHAVIOR OF THE DPRK AUTHORITIES TOWARD THE INFLOW OF FOREIGN INFORMATION}

North Korean authorities have been trying to respond to the effects of providing information from abroad for years. The law represses the use of smuggled devices and data carriers, as well as access to external broadcasts or the dissemination of rumors that destroy the social order (Kretchun \& Kim, 2012, p. 70). Receiving foreign radio or TV stations and having illegal publications is treated as a crime against the state and may be punishable by heavy works, imprisonment, or even death (Baek, 2016). The amended Penal Code of 2004 set the punishment of staying in a labor camp or correctional institution for importing illegal photographs, CDs or VHS tapes containing foreign music, films and pornographic materials. 
Article 195 of the Penal Code forbade listening to South Korean broadcasts and collecting and disseminating printed materials from the South and spreading the information heard. Article 222 stated that the dissemination of false messages causing distrust of the state or disturbing the social order is punishable by two years of forced labor. The punishment for tracking the South Korean media was the imprisonment of two years in a re-educational labor camp for up to five years in a prison camp. In reality, however, it often depended on the social status of the accused and his ability to pay a bribe (Kretchun \& Kim, 2012, p. 71).

In 2007, the Penal Code was changed. New regulations were supposed to additionally increase control over the society and tighten punishments for some offenses related to obtaining information from abroad. For example, since then illegal cooperation with someone living in another country was to be punished with a stay in a labor camp for three to five years. In addition, there is the lack of precision in such terms as: "particularly serious circumstances" or "very serious matter", that may lead to arbitrary treatment of defendants and condemning them to harsh sentences even for minor offenses (Kretchun \& Kim, 2012, p. 72).

\section{POTENTIAL INFLUENCE OF FOREIGN INFORMATION ON THE DPRK POPULATION}

It is also worth considering how much the desire to access foreign information is caused by a real desire to learn the truth about the policy of North Korean authorities and the readiness of citizens to change their views. As pointed out by N. Kretchun and J. Kim, some recipients of the external media are not looking for information to convince themselves of the manipulation of the regime, but of mere curiosity or entertainment. In addition, due to the isolation of North Korea from the foreign media, it is often difficult to comment on political events in this country. For this reason, national media are actually the only ones able to relate to current social and political situations (Kretchun \& Kim, 2012, p. 13). One cannot assume that information from abroad will have an immediate effect and change the North Korean people's beliefs inculcated in them for decades. In any case, North Koreans do not necessarily believe everything they see. Andrei Lankov noticed that in the $1970^{\mathrm{s}}$ and $1980^{\mathrm{s}}$ the citizens of the European communist bloc states, thanks to - among others - foreign radio programs, learned about life in Western countries, which deprived the state authorities of their credibility and raised the curiosity of the outside world (Lankov, 2009, p. 4). Due to the 
conditions at the time, the influence of, e.g., Radio Free Europe in Poland during the communist dictatorship, was different. The vast majority of Polish society in fact distanced themselves from the theses proclaimed by the state authorities. The propaganda used in DPRK is in turn based on the real painful historical experiences of the Korean people and the stimulation of nationalist sentiments. It is therefore difficult for foreign messages to be absorbed there with the same ease as the aforementioned content transmitted to Poles in the 1980s. As in Poland, the inflow of foreign information led to linguistic changes through the utilization of foreign words. Young North Koreans started to use South Korean slang (Baek, 2016, p. 187), just as Poles in the $1970^{\text {s }}$ used American words.

According to a research conducted by N. Kretchun and J. Kim, foreign media seem to be credible to Koreans from the North. Despite this, it does not affect the attitude of citizens towards their authorities too much (Kretchun \& Kim, 2012, p. 33). Access to foreign information sources, however, affects the more favorable perception of the United States and South Korea (Kretchun \& Kim, 2012, p. 24). It should be remembered that the citizens of North Korea do not have the opportunity to express their views, let alone engage in activities that could cause significant changes in the country (Kretchun \& Kim, 2012, p. 31). It is also worth taking into account that when examining the attitudes of refugees, we often deal with people who believed in foreign messages and on this basis decided to escape from their homeland. However, it is difficult to draw conclusions from such results in the context of the entire population of the DPRK. For example, the individual character traits of these people, or the region of residence, where it is easier to access news from abroad, could be important.

\section{CONCLUSION}

The inflow of foreign information to North Korea is a process that will be very difficult to slow down in spite of the efforts of the DPRK relevant authorities. On the basis of the data provided in this article, the regime from Pyongyang not only strengthens and extends methods of control and isolation of citizens, but also introduces changes to the law. However, by applying pressure to the authorities in South Korea, the DPRK government tries to influence the actions of people undertaking initiatives outside the borders of the DPRK. Yet, we can expect that despite threats, smuggling of goods and the efforts of foreign activists and the media will be continued. As a result, knowledge about living conditions in other 
countries will spread. For many years, in North Korea there was a situation in which - contrary to the beliefs of many people in the Western world - citizens, due to isolation and propaganda, were indeed devoted to national leaders and ideas. Through the flow of information, this belief will most likely be subject to gradual disappearance. This may be the reason for the growing discord between the declared views and the theses proclaimed by the media, and the real feelings of the ever-wider circles of society. It does not seem, however, that the current time should be groundbreaking. Regarding leaflets sent to North Korea, the influence of such actions is still limited as the South Korean government is reluctant. We consider that this initiative would be much more efficient being supervised from the Chinese border. However, it would need the approval of Chinese authorities, which would rather cooperate with North Korean authorities.

Furthermore, as there are regular repression campaigns, there is also a lack of trust between people, which would enable unity and undertaking joint actions aimed at changing the government. However, the standard of living is not as tragic as in the second half of the 1990s. It is also not easy to quickly destroy the myth built in the minds of Koreans from the North for seven decades. Due to the centralization of power, there are also no educated mechanisms or even a tradition of bottom-up political activity. People from the top of power are often beneficiaries of the regime. It is difficult to expect both rapid changes from the bottom-up as well as those inspired by the political elite. As a result, it helps to maintain the status quo, which may after all become more and more vulnerable in the future. In the case of North Korea, the main firewall consists of the Chinese authorities.

\section{ReFERENCES:}

Baek, J. (2016). North Korea's Hidden Revolution: How the Information Underground is Transforming a Closed Society. New York \& London: Yale University Press.

Baek, J. (2016, October 19). Why Foreign Information in North Korea Is Such a Big Deal? Retrieved from: www.nknews.org/pro/why-foreign-information-in-north-koreais-such-a-big-deal.

BBC (2011, December 19). North Korea's Tightly Controlled Media. Retrieved from: www.bbc.com/news/world-asia-pacific- 16255126.

Chun, S. (2008, February 27). Radio Gives Hope to North and South Koreans. Retrieved from: http://edition.cnn.com/2008/WORLD/asiapcf/02/27/cho.dissidentradio.

Colors (2013, April 9). North Koreans Found Out about Qaddafis Death from Leaflets Falling Out of the Sky. Retrieved from: www.colorsmagazine.com/stories/maga- 
zine/86/story/northkoreans-found-out-about-qaddafis-death-from-leaflets-fallingout-of-t.

Demick, B. (2011). Światu nie mamy czego zazdrościć. Zwyczajne losy mieszkańców Korei Północnej. Wołowiec: Wydawnictwo Czarne.

Faiola, A. (2005, August 10). An Act of Subversion, Carried by Balloons: A Korean Missionary Sends Aerial Messages of Faith Over Border to North. Retrieved from: www. washingtonpost.com/wpdyn/content/article/2005/08/09/AR2005080901402.html.

Farivar, C. (2014, February 25). North Korean Defector Fights Pyongyang with Thumbdrive-laden Balloons. Retrieved from: http://arstechnica.com/tech-policy/2014/02/ north-korean-defector-fights-pyongyang-with-thumbdrive-laden-balloons.

Freedom House (2016). North Korea. Retrieved from: https://freedomhouse.org/report/ freedom-press/2016/north-korea.

Higginbotham, A. (2014, June 6). The No-Tech Tactics of North Korea's Most Wanted Defector. Retrieved from: www.bloomberg.com/news/articles/2014-06-05/the-notech-tacticsof-north-koreas-target-zero-park-sang-hak.

Joy, A. (2014, November 11). Conflict Over Balloon Launch Near North-South Korean Border. Retrieved from: www.koreabang.com/2014/stories/conflict-over-releaseof-anti-north-korealeaflets.html.

Jung, J.-h. (2014). Ballooning Evangelism: Psychological Warfare and Christianity in the Divided Korea. Göttingen: Max-Planck-Institut zur Erforschung multireligiöser und multiethnischer Gesellschaften.

Kim, M. (2012). Z piekła do wolności. Ucieczki z Korei Północnej. Warszawa: Wydawnictwo Naukowe PWN.

Kretchun, N., \& Kim, J. (2012). A Quiet Opening: North Koreans in a Changing Media Environment [report]. Washington: InterMedia.

Lankov, A. (2009). Changing North Korea: An Information Campaign Can Beat the Regime. Foreign Affairs, 88(6), 95-105.

Lankov, A. (2014). The Real North Korea: Life and Politics in the Failed Stalinist Utopia. Oxford: Oxford University Press.

McDonald, M. (2011, April 27). Balloon-Borne Messages to North Korea Have Detractors on Both Sides of Border. Retrieved from: www.nytimes.com/2011/04/27/world/ asia/27iht-korea.html.

Dearden, L. (2016, February 2). North Korea Sends Balloons 'Filled with Toilet Paper and Rubbish' over Border as Propaganda War Continues. Retrieved from: www. independent.co.uk/news/world/asia/north-korea-sends-balloons-filled-withtoiletpaper-and-rubbish-over-border-as-propaganda-war-a6849146.html.

Pearson, J. (2015, March 27). The \$50 Device That Symbolizes a Shift in North Korea. Retrieved from: www.reuters.com/article/us-northkorea-change-insight idUSKBN0MM2UZ20150327.

Russon, M.A. (2016, May 26). North Korea: Activists Use Drones to Deliver USB Sticks with Information about Outside World. Retrieved from: www.ibtimes.co.uk/ north-koreaactivists-use-drones-deliver-usb-sticks-information-about-outsideworld-1562134. 
Sang-hun, C. (2016, October 15). A „Balloon Warrior”Subverts North Korea, Thousands of Leaflets at a Time. Retrieved from: https://www.nytimes.com/2016/10/15/world/ asia/south-north-korea-balloon-drop.html.

Sedaghat, N. (2014, March 17). North Korea Exposed: Censorship in the World's Most Secretive State. Retrieved from: www.cjfe.org/north_korea_exposed_censorship_in_the_world_s_most_secretive_state.

Shim, E. (2015, December 11). Defector Flew Drones Carrying Flash Drives into North Korea. Retrieved from: www.upi.com/Top_News/World-News/2015/12/11/ Defector-flew-dronescarrying-flash-drives-into-North-Korea/1501449850667.

Talmadge, E. (2014, February 23). North Korea: Where the Internet has just 5,500 Sites. Retrieved from: www.thestar.com/news/world/2014/02/23/north_korea_where_ the_internet_has_just_5500_sites.html.

The Guardian (2015, April 8). Balloon Activist Sends 'Thousands of Copies' of 'The Interview' to North Korea. Retrieved from: www.theguardian.com/film/2015/apr/08/ balloon-activist-sends-thousands-of-copies-of-the-interview-to-north-korea.

Ziccardi, G. (2013). Resistance, Liberation, Technology and Human Rights in the Digital Age. Dordrecht, Heidelberg, New York, London: Springer. 